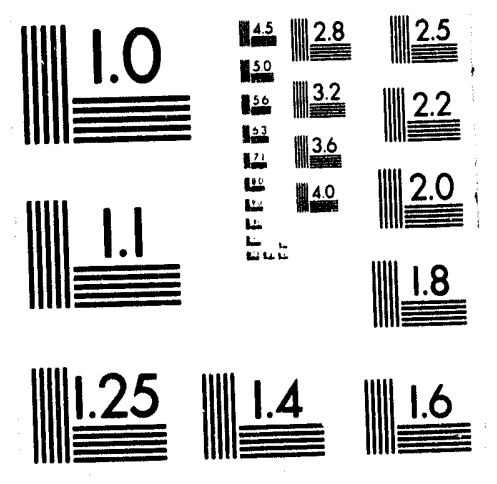



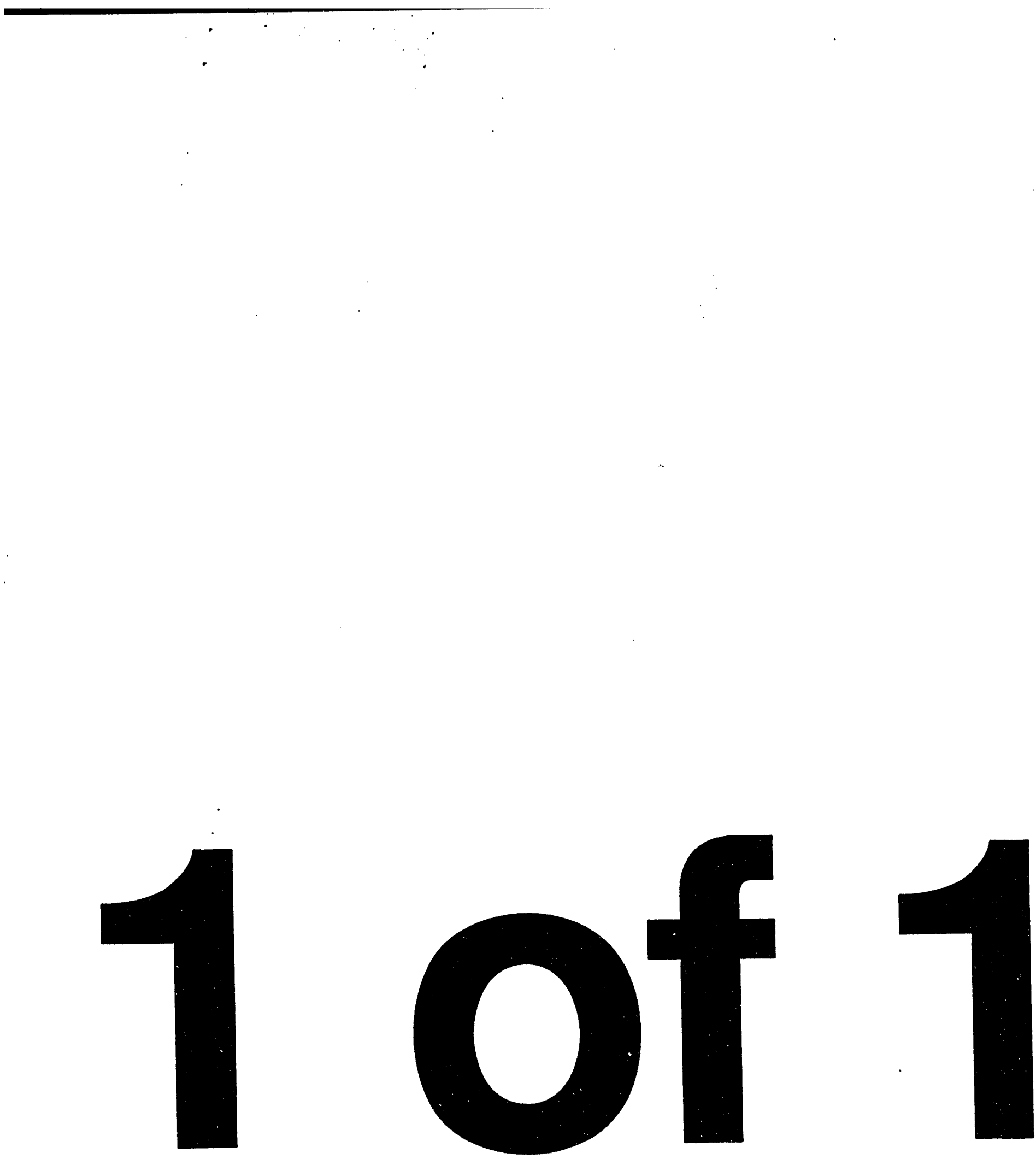
Energy Systems Environmental Restoration Program ORNL Environmental Restoration Program

\title{
Best Management Practices Plan for Environmental Monitoring in Waste Area Grouping 6 at Oak Ridge National Laboratory, Oak Ridge, Tennessee
}

Manuscript Completed-October 1993

Date Issued-February 1994

\author{
Prepared by \\ Gilbert/Commonwealth, Inc. \\ Oak Ridge, Tennessee \\ under subcontract 32K-UB147C
}

Prepared for

U.S. Department of Energy

Office of Environmental Restoration and Waste Management

under budget and reporting code EW 20

OAK RIDGE NATIONAL LABORATORY

Oak Ridge, Tennessee 37831-6285

managed by

MARTIN MARIETTA ENERGY SYSTEMS, INC.

for the

U.S. DEPARTMENT OF ENERGY

under contract DE-AC05-84OR21400 
Best Management Practices Plan for Environmental Monitoring in Waste Area Grouping 6 at Oak Ridge National Laboratory, Oak Ridge, Tennessee

Approvals

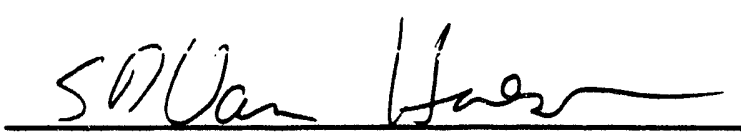

S. D. Van Hoesen, Project Engineer

Corelli Valutmos

C. K. Valentine, Environmental Management
$10118 / 93$

Date

$10 / 14 / i 3$

Date 


\section{CONTENTS}

EXECUTTVE SUMMARY $\ldots \ldots \ldots \ldots \ldots \ldots \ldots \ldots \ldots \ldots \ldots \ldots$

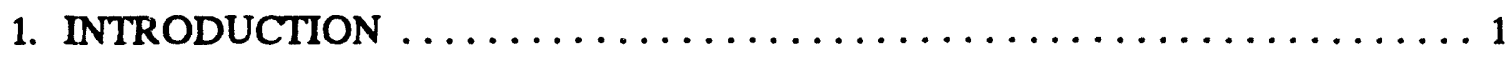

2. SITE AND PROGRAM DESCRIPTION $\ldots \ldots \ldots \ldots \ldots \ldots \ldots \ldots \ldots$

3. EMPLOYEE TRAINING $\ldots \ldots \ldots \ldots \ldots \ldots \ldots \ldots \ldots \ldots \ldots \ldots$

4. PRINCIPAL SAFETY, FIRE, AND HEALTH iAZARDS $\ldots \ldots \ldots \ldots \ldots \ldots$

5. SPILL PREVENTION AND CONTROL $\ldots \ldots \ldots \ldots \ldots \ldots \ldots \ldots \ldots \ldots$

6. WASTE CHARACTERIZATION AND MANAGEMENT MONITORING $\ldots \ldots 7$

7. GOOD HOUSEKEEPING PRACTICES $\ldots \ldots \ldots \ldots \ldots \ldots \ldots \ldots \ldots$

8. INSPECTIONS FOR ENVIRONMENTAL COMPLIANCE . ......... 9

9. SEDIMENT AND EROSION CONTROL MEASURES $\ldots \ldots \ldots \ldots \ldots \ldots \ldots \ldots$

10. REFERENCES $\ldots \ldots \ldots \ldots \ldots \ldots \ldots \ldots \ldots \ldots \ldots \ldots \ldots \ldots \ldots \ldots \ldots \ldots \ldots$ 


\section{EXECUTIVE SUMMARY}

This Best Management Practices (BMP) Plan has been developed as part of the environmental mcisitoring program at Waste Area Grouping (WAG) 6. The BMP Plan describes the requirements for personnel training, spill prevention and control, environmental compliance, and sediment/erosion control as they relate to environmental monitoring activities and installation of Monitoring Station 4 at WAG 6. 


\section{INTRODUCTION}

The purpose of this document is to provide the environmental monitoring program a sitespecific Best Management Practices (BMP) Plan for Waste Area Grouping (WAG) 6 at the Oak Ridge National Laboratory (ORNL), Oak Ridge, Tennessee.

Section 304(e) of the Clean Water Act enables the Administrator of the U.S. Environmental Protection Agency (EPA) to establish requirements for the control of pointsource releases of pollutants. The National Pollution Discharge Elimination System requires that facilities with the potential for releasing pollutants to the waters of the United States submit a BMP Plan, as specified in 40 CFR 125, Subpart $\mathrm{K}$, as a part of the discharge permit application.

According to Martin Marietta Energy Systems, Inc., (Energy Systems) Environmental and Waste Management Policy (ES\&H-14)," "It is company policy to establish and to maintain waste management, pollution control, and surveillance programs which are consistent with the company and Department of Energy (DOE) policy and which meet the requirements of federal, state, and local regulations to assure that installation personnel, the general public, and the environment are protected against hazardous pollutants."

Implementation of the BMP Plan will be initiated by providing a copy to all parties involved in field activities for installing Monitoring Station 4, installing piezometers and groundwater quality wells, and environmental monitoring. Recurring, formal site inspections will be made and recorded to ensure compliance with the provisions of this plan.

The environmental monitoring program at WAG 6 will be managed and operated by the ORNL Environmental Restoration Program and its subcontractors. 


\section{SITE AND PROGRAM DESCRIPTION}

The site for this project is located inside WAG 6 at ORNL. WAG 6 has been used as a shallow burial site for hazardous and low-level radioactive waste at ORNL since 1969. WAG 6 is located within the Oak Ridge Reservation and is situated in Melton Valley between Haw Ridge and Copper Ridge. WAG 6 consists of three contaminated sites: (1) Solid Waste Storage Area (SWSA) 6, (2) the explosives detonation trench, and (3) the emergency waste basin. SWSA 6, the largest of the contaminated WAG 6 sites and the principal source of contamination at WAG 6, was used as a deposit site for a variety of radioactive, chemical, biological, and mixed wastes. The explosives detonation trench, a deep trench in the southeast corner of SWSA 6, was used to contain debris from the detonation of explosive materials and was backfilled following use. The emergency waste basin was constructed as an emergency holding basin for waste from the ORNL main plant area. Although the emergency waste basin, a 20 -acre area located in the northeast corner of the WAG, was reportedly never used, it contains contaminated groundwater and surface water runoff from the upgradient SWSA $6 .^{2}$

The WAG 6 Environmental Monitoring Plan calls for the monitoring of surface water discharges, groundwater quality and level, seeps and springs water quality and flow, and meteorological conditions in WAG 6 for -5 years. To support this monitoring, a new Monitoring Station 4 will be constructed in the northeast corner of WAG 6 in the vicinity of the emergency waste basin, and several new groundwater wells and piezometers will be installed. This BMP Plan will address the activities required for the installation of Monitoring Station 4, the new groundwater wells and piezometers, and the environmental monitoring.

The civil portion of the Monitoring Station 4 installation activity includes construction of a drainage channel, a box culvert, and a fiberglass $\mathrm{H}$ flume. Installation of the groundwater quality wells involves the use of an auger to drill several wells that range in depth from 25 to $60 \mathrm{ft}$. The groundwater piezometers, approximately $20 \mathrm{ft}$ in depth, will be installed using the drive point method, where possible, or an auger, as an alternative.

The instrumentation portion of the work will include installation of a variety of automatic and manual systems. For surface water monitoring, an integrated water runoff monitoring system consisting of flow meters, sample systems, and data logging and retrieval systems will be used. The monitoring system will be operated continuously; however, samples will be retrieved periodically for analysis at a remote location. Several of the piezometers will be equipped with continuous data recorders. All groundwater quality wells will be instrumented with dedicated sampling devices. For seeps and springs monitoring, no permanent electronic equipment will be used at the sampling locations; grab samples will be taken periodically for analysis. Meteorological instruments will be mounted on a $2-\mathrm{m}$ tower located near the center of WAG 6. Installation of electric power supplies and distribution systems with sufficient capacity to serve the monitoring equipment and supporting auxiliary equipment will also be required for Monitoring Station $4^{3}$

The monitoring equipment will be calibrated during initial installation and periodically during the monitoring program to ensure that the data obtained will meet the data quality objectives. 
The surface water sampling stations automatically measure and record flow and water level and collect water samples. Several piezometers automatically obtain water level measurements. Manual sampling will be required for groundwater quality, seeps and springs monitoring, some groundwater level measurements, and specific surface water data. Meteorological data are collected automatically. Periodically, personnel will retrieve the data from the automatic systems and inspect and maintain the equipment. 


\section{EMPLOYEE TRAINING}

Energy Systems employees receive a broad range of environmental, safety, and health training [e.g., Superfund Amendments and Reauthorization Act and Occupational Safety and Health Administration (OSHA)] based on their job requirements. Environmental awareness is raised by issuing periodic bulletins concerning topics such as spill control. Supervisors are responsible for providing on-the-job training with respect to hazardous materials handling and company environmental policy.

Contractors and subcontractors performing work at the WAG 6 project site will be required to comply with Energy Systems and DOE environmental policy, including the provisions of this BMP Plan. All personnel performing field activities are to perform the work as described in the sampling and analysis plans (SAPs), the construction and design specifications, the project site health and safety plan, the project waste management plan, and as directed by the WAG 6 Project Manager.

All sampling technicians will receive detailed training on the project work plans and the specific SAPs for surface water, groundwater, seeps and springs, and meteorological monitoring. These detailed plans include requirements for handling the potentially contaminated samples, controlling sample purge water, and data collection requirements. Additional training will be conducted on the project-specific health and safety plan and the waste management plan. 


\section{PRINCIPAL SAFETY, FIRE, AND HEALTH HAZARDS}

WAG 6 environmental monitoring equipment and procedures will conform with all ORNL safety requirements. Use of the latest editions of the applicable codes is required.

Standard health and safety procedures will be established for work at the WAG 6 project site including a site-specific health and safety plan that meets all applicable DOE, ORNL, OSHA, and EPA requirements. It will detail a Site Health and Safety Officer and site organization and specify expected hazards, required training and medical surveillance, exposure monitoring, work zone establishment and safe working practices, protective clothing and equipment, contamination control, and emergency response.

During installation of Monitoring Station 4 and the drilling of new groundwater wells, earth moving operations and general field activities will be subject to normal industrial hazards, and appropriate precautions will be taken. 


\section{SPILL PREVENTION AND CONTROL}

Spill Prevention Control Countermeasures and Contingency Plans for Oak Ridge National Laboratory ${ }^{4}$ provides details concerning roles and responsibilities of personnel responding to releases of oils or hazardous substances. Only that portion directly related to field activities of the WAG 6 environmental monitoring is summarized here.

The project Construction Engineer is charged with the responsibility to ensure that effective spill preventative measures are in place. The Office of Environmental Compliance and Documentation (OECD) will provide oversight and guidance.

Reference 4 requires that all possible precautions be taken to minimize the likelihood of a spill and, in the event of a spill or release, that they are safely contained and recovered in a manner that best ensures personnel safety and protection of the environment.

All tanks over $5 \mathrm{gal}$ are required to be labelled with the appropriate hazardous identification placards (diamond), as identified in the National Fire Protection Association Code (NFPA-704). ${ }^{5}$ Tanks, drums, and other containers of hazardous or toxic material, such as cleaning solvents, some detergents, degreasers, etc., will require secondary containment while stored on-site. Guidelines for design and construction of hazardous material storage tanks and secondary containment are specified in Design Standards for Hazardous/Toxic Waste and Material Storage Tanks, Dikes, and Transfer Stations, Y/TS-104. ${ }^{6}$

All heavy equipment and mechanical equipment will be maintained in good repair to minimize the release of engine, transmission, or other oils through slow leaks. Idle equipment will be parked as far away from streambeds or drainage pathways as practical. At the request of the Construction Engineer, a drip pan provided by the contractor will be used under equipment leaking significantly. Repairs to correct any substantial leaks will be effected as soon as possible.

Fueling operations will be performed with care to prevent inadvertent small releases. It is expected that material spilled by contractors, if any, will be reported to Energy Systems and cleaned up as soon as possible, placed in appropriate containers, and disposed of in accordance with Waste Management Operation procedures mandated by the Construction Engineer.

If a spill occurs at the WAG 6 site, all safe and practical methods available should be used to prevent material from entering streams, creeks, or springs. Spill control kits containing absorbent material will be provided at the site. Absorbent pillows, temporary earth dikes, or other readily available means should be employed, as appropriate, without risking personnel safety. Specific emergency procedures for a spill or leak will be included in the site-specific health and safety plan.

During environmental monitoring, all potentially contaminated samples and sample purge water must be properly stored in labelled containers to prevent spillage, as specified in the SAPs. 


\section{WASTE CHARACTERIZATION AND MANAGEMENT MONITORING}

Materials generated during the installation of monitoring equipment and during sampling operations will be field monitored, classified appropriately, and collected and disposed of in accordance with the project waste management plan. Sampling and analysis for site characterization show that radiologically contaminated soil meeting Category 2 criteria per ORNL/M-116/R1 ${ }^{7}$ may be encountered during excavation activities. It is unlikely that Category 3 soil will be encountered. Generation of some radioactive waste is also likely, based on current site characterization sampling.

During excavation, the material removed will be monitored with portable radiation detectors for Ref. 7 limits and with portable ionization detectors for volatile organics. If contaminants are detected, they will be segregated and stockpiled on polyvinyl sheeting for handling. The stockpiled material will be covered to prevent contamination spread by dispersion or leaching by rainwater.

During sampling activities, all sample containers, sampling equipment, and protective clothing will also be monitored for Ref. 7 limits and volatile organics. 


\section{GOOD HOUSEKEEPING PRACTICES}

Good housekeeping practices will be observed by all personnel present at the field sites at all times. Paper trash and refuse will be contained, collected, and disposed of at an appropriately permitted facility. Portable toilets will be maintained so that their contents are contained. Well purge water or unused sample water will be collected and contained and subsequently analyzed by an Analytical Projects Office approved laboratory to determine the presence of any contaminants. If no contaminants are identified in the results of laboratory analysis, the OECD will be consulted before the water is discharged on-site. All rinse water containing additives of any sort (i.e., soap, degreasers, and cleaning agents) will be collected, contained, and disposed of. Trucks hauling material on- and off-site will not be overfilled. Loose debris will te contained within the vehicles to prevent littering of highways and haul roads. Brush, construction debris, and trash will be removed from drainage paths and creeks. Burning of construction debris and brush will not be permitted without an approved burning plan.

Fueling operations will be conducted so that any small fuel or oil releases are contained and cleaned up as soon as possible. All possible precautions are to be taken to minimize discharge of fuel, oil, lubricants, grease, and other hydrocarbons.

Suitable staging areas will be provided and used to support waste management activities of the WAG 6 Environmental Monitoring Plan, including staging, handling, and packaging facilities, as appropriate for the particular conditions encountered. The staging areas will be established and controlled to prevent the dispersal of radioactive or hazardous contamination, if encountered, to the surrounding environment. Suitable laydown areas will be provided for temporary storage of the construction materials and tools. Soils will be stockpiled on-site in SWSA 6 to facilitate their use as backfill or below-grade fill. These stockpiles will be placed as far away from streambeds or drainage pathways as practical. The soil will be placed on suitable polyvinyl sheeting and covered with additional polyvinyl sheets, and silt fencing will be used, as necessary, to prevent erosion of the loose soil. Additional precautions, as defined in the project waste management plan, may be required if radioactive contamination or Resource Conservation and Recovery Act hazardous wastes are encountered. 


\section{INSPECTIONS FOR ENVIRONMENTAL COMPLIANCE}

The Construction Engineer and OECD personnel will perform periodic site inspections during installation of Monitoring Station 4, groundwater quality wells, and piezometers to confirm compliance with all environmental regulations and policies, including those set forth in this BMP Plan.

Items to be inspected may include, but are not limited to,

- field construction activities, including

- waste cover consolidation and

- positive storm water drainage;

- condition of erosion control structures, including

- silt fence,

- $\quad$ areas to be seeded, and

- placement of hay/straw bales;

- general housekeeping on-site;

- evidence of poor fueling practices;

- evidence of leaking tanks or equipment;

- inspection of creek waters for oil sheen, debris, seeps, siltation, or other disturbances;

- inspection of contractor records, including types and quantities of hazardous/toxic materials on-site; and

- inspection of safe storage of hazardous or toxic materials (i.e., material compatibility; diked, if required).

A written record, including the date and findings of the inspection and notification of the appropriate party, will be issued. It is expected that any deficiencies noted by the Construction Engineer or OECD will be corrected by the contractor as soon as possible.

During the environmental monitoring activities at WAG 6, periodic site inspections will be made by OECD personnel to confirm compliance with all environmental regulations and policies, including those set forth in this BMP Plan. Upon notification, the project Construction Engineer will arrange for any deficiencies to be corrected immediately, or as soon as practical. Items to be inspected during the monitoring activities may include, but are not limited to,

- general housekeeping on-site;

- evidence of poor fueling practices;

- evidence of improper handling of purge water generated during sampling operations;

- inspection of leaking tanks or equipment;

- inspection for safe storage of hazardous or toxic materials (i.e., material compatibility; diked, if required);

- inspection of creek waters for oil sheen, debris, siltation, or other disturbances;

- inspection of sample stations to ensure that all potentially hazardous materials are contained; and

- inspection of sampling stations to ensure that sampling systems are not diverting stream flow, causing erosion or other detrimental conditions. 


\section{SEDIMENT AND EROSION CONTROL MEASURES}

A primary concern of this BMP Plan is to provide effective erosion and sediment control. Several excellent references are available $;^{8-10}$ however, this chapter of the WAG 6 BMP Plan follows guidance provided by the U.S. Department of Transportation's (DOT's) Best Management Practices for Erosion and Sediment Control. ${ }^{11}$ Because of the interaction of various sediment and erosion control features within the site area, it is important that all site work conform to the applicable specifications. Deviation from the design requires prior authorization from the WAG 6 Project Manager. The sequence in placing the various control features specified must be followed.

The WAG 6 project team has not determined whether Monitoring Station 4 will be installed; however, the following steps will be followed if Monitoring Station 4 is installed. The outfall monitored by Monitoring Station 4 is typically dry, except during drainage of the emergency waste basin or during rainfall events. Optimally, Monitoring Station 4 will be constructed during the fall dry season, and no flow will occur through the streambed. If wet weather prevails, pumps will be used to control drainage, and flow diversion will be provided to prevent concrete washout to the WAG 6 tributaries. A staircase will be installed for access to the flume and monitoring equipment. Physical methods, if possible, or short-lived herbicide in minimal quantity will be used to remove any vegetation that obstructs access to the flume; 10 to $15 \mathrm{ft}^{3}$ of soil will be excavated to install the approach section and a wing wall. The soil will be used for the wing wall and for stabilization around Monitoring Station 4 . The erosion control techniques used will prevent the herbicide from damaging additional flora, fauna, and aquatic species. In the excavation areas, walk boards will be used to minimize erosion, and the areas will be reseeded and mulched immediately. If concrete is poured, straw bales and silt fencing will be used as a deterrent to sediment and concrete wash water leaving the area. Additionally, the construction contractor will be instructed not to rinse concrete equipment except in designated areas or off-site, at a controlled wash station.

Several actions to lessen the environmental impact caused by erosion will be taken during the field activities phase of the WAG 6 Environmental Monitoring Plan, particularly during the Monitoring Station 4 sample station construction and well installation.

- Creek crossing (fording) by heavy equipment will be minimized and limited to specific locations, where mats or other protective measures have been installed to reduce disturbances of the creek bed. OECD will be contacted during design, well in advance of construction, for determination of any environmental permits required for the stream crossings, especially for culvert-type crossing installations. The environmental permit determinations will address whether the activities are subject to policy directives for federal response actions under CERCLA (40 CFR 300).

- Riprap or geotextile fabric-lined drainage ditches and/or perforated pipe will be installed to drain construction areas.

- Erosion control matting will be placed on steep slopes, if any, to reduce the potential for erosion.

- In accordance with DOT guidance, silt fences, sediment traps, and ditches will be installed immediately following tree clearing, if any, and before grubbing, scalping, and filling.

- Periodic inspection will be made to verify that silt fencing is in operational condition. 
- Hay/straw bales will be replaced as needed.

- Stream diversion channels will be lined with geotextile fabric, riprap, or similar suitable material. Stream diversion activities must be evaluated in advance by the Construction Engineer for potential permitting requirements.

- Culvert entrances and exits will be protected with riprap.

- Seeding and mulching will immediately follow the development of each construction segment.

Following any required excavation or drilling activities in WAG 6, the following practices must be maintained during the monitoring phase:

- Ditches and drain ways will be periodically cleared of brush/debris.

- Habitat disturbances will be minimized during clearing.

- Permanent silt fences, if any, and sediment control structures will be maintained in operational condition.

- Silt accumulation will be removed, as needed, and disposed of at an approved disposal site.

- Vegetative cover will be maintained so that bare spots are minimized. 


\section{REFERENCES}

1. Environmental and Waste Management Policy, ES\&H-14, Martin Marietta Energy Systems, Inc., May 1985.

2. RCRA Facility Investigation Report for Waste Area Grouping 6 at Oak Ridge National Laboratory, Oak Ridge Tennessee, ES/ER-22, ORNL/ER/Sub 87-99053/5, Martin Marietta Energy Systems, Inc., 1991.

3. Environmental Monitoring Plan for Waste Area Group 6 at Oak Ridge National Laboratory, Oak Ridge, Tennessee, DOE/OR/01-1192 \& D1, Martin Marietta Energy Systems, Inc, 1993.

4. Spill Prevention Control Countermeasures and Contingency Plans for Oak Ridge National Laboratory, ORNL/M-1082, Martin Marietta Energy Systems, Inc., 1990.

5. Standard System for the Identification of the Fire Hazards of Material, NFPA-704, National Fire Protection Association, 1961.

6. Design Standards for Hazardous/Toxic Waste and Materials Storage Tanks, Dikes and Transfer Stations, Y/TS-104, Martin Marietta Energy Systems, Inc., 1985.

7. Health, Safety, and Environmental Protection Procedure for Excavating Operations, ORNL/M-116, R1, Martin Marietta Energy Systems, Inc.

8. Comparative Costs of Erosion and Sediment Control, Construction Activities, EPA 430/9. 73-016, U.S. Environmental Protection Agency, July 1973.

9. Guidelines for Erosion and Sediment Control Planning and Implementation, EPA-R2-72015, U.S. Environmental Protection Agency, August 1972.

10. Erosion and Sediment Control Handbook for Urban Areas and Construction Sites in Tennessee, U.S. Department of Agriculture, 1974.

11. Best Management Practices for Erosion and Sediment Control, U.S. Department of Transportation, December 1978. 


\section{DISTRIBUTION}

1. H. L. Boston

2. S. B. Garland

3. L. L. Kaiser

4. C. W. Kimbrough

5. A. J. Kuhaida, Jr.

6-8. D. M. Matteo

9. T. J. Newsom

10-11. P. T. Owen

12. P. A. Schrandt

13. S. D. Van Hoesen

14. M. L. Whitehead

15. A. S. Will

16. P. S. Wood

17. Central Research Library

18-20. Central ER Document Management Center

21-23. ORNL ER Document Management Center

24. Laboratory Records Department

25. ORNL Patent Section

26. Office of Assistant Manager for Energy Research and Development, DOE Oak Ridge Operations Office, P.O. Box 2001, Oak Ridge, TN 37831-8600

27-28. Office of Scientific and Technical Information, P.O. Box 62, Oak Ridge, TN 37831 
11
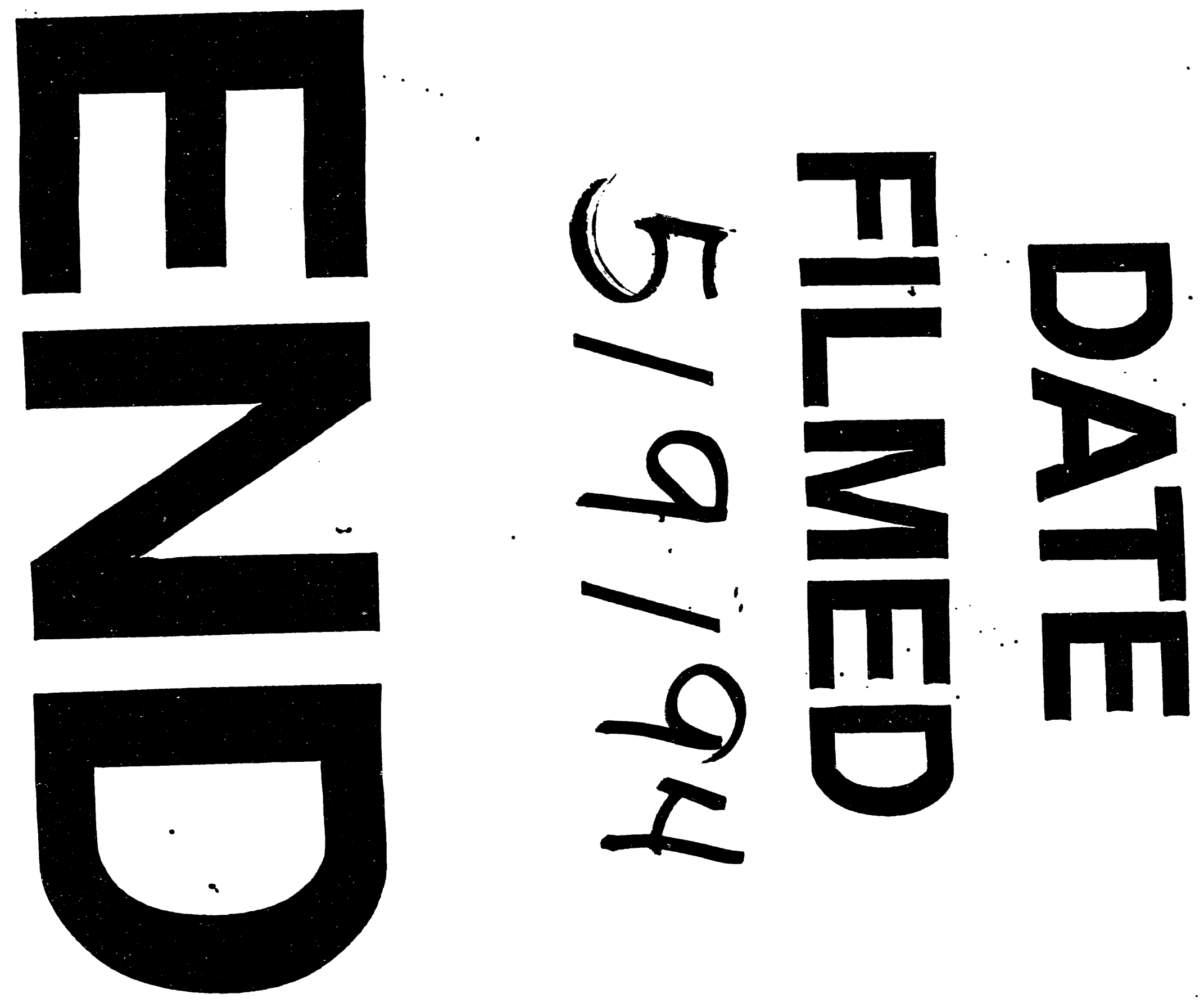


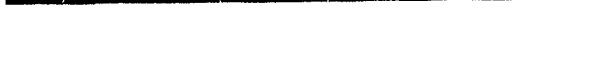

$$
-
$$

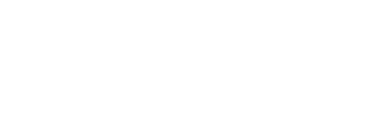

